KRZYSZTOF CZYŻAK

Instytut Filmu, Mediów i Sztuk Audiowizualnych

Wydział Filologii Polskiej i Klasycznej

Uniwersytet im. Adama Mickiewicza w Poznaniu
Images

vol. XXIX/no. 38

Poznań 2021

ISSN 1731-450x

\title{
Kolonizacja stawów hydr - narracje $w$ serii Heroes of Might and Magic
}

\begin{abstract}
Czyżak Krzysztof, Kolonizacja stawów hydr - narracje $w$ serii Heroes of Might and Magic [Hydra Ponds' Colonization - Narratives in the Heroes of Might and Magic Series]. "Images" vol. XXIX, no. 38. Poznań 2021. Adam Mickiewicz University Press. Pp. 205-219. ISSN 1731-450X. DOI 10.14746/i.2021.38.13.

This article is an analysis of narratives in a series of video games called Heroes of Might and Magic. Author discusses issue of colonial/imperial thinking connected with strategy genre, evolution of fantasy tropes and developement of plot structure. On this basis he tries to outline the limitations of storytelling which result from series formula.
\end{abstract}

KEYwORDs: Heroes of Might and Magic, turn-based strategy, fantasy, cRPG, video games

Seria gier cyfrowych Heroes of Might and Magic zdobyła rzeszę fanów w Polsce - szczególnie jej trzecia odsłona z 1999 roku należy do grona produkcji z przełomu wieków, które wpłynęły na tożsamość polskich graczy[1] i nadal cieszą się niesłabnącą popularnością. Świadczyć o tym mogą aktywne grupy na portalu Facebook, mające tysiące członków (Hirawka - JBwA sekcja Heroes of Might and Magic[2], Klub horej czaszki[3]), kilka fanpage'y z memami wykorzystującymi elementy gry (Astrologowie ogłaszają [4], Sok z Crag Hacka [5]), różnorakie portale prowadzone przez miłośników serii (Jaskinia Behemota[6], Kwasowa grota[7]), fanowska orkiestra, która skupia się na odgrywaniu własnych aranżacji utworów skomponowanych na potrzeby serii przez Paula Anthony'ego Romero (Heroes Orchestra[8]) czy wreszcie - istnienie ogólnopolskich i międzynarodowych turniejów (na przykład Mistrzostw Polski w Heroes of Might and Magic III[9]).

W rozgrywce celem gracza jest zarówno ekspansja królestwa w cyfrowej rzeczywistości fantasy, jak i rozwój tytułowych herosów, postaci od-

[1] Vide: S. Krawczyk, „Przed wyruszeniem $w$ droge należy zebrać drużynę". Dlaczego gry komputerowe z przełomu wieków wplynęly na tożsamość polskich graczy?, „Homo Ludens” 2015, nr 2 (8), s. 63-79.

[2] <https://www.facebook.com/groups/hirawka/>, dostęp: 23.01.2021.

[3] Pisownia oryginalna, $<$ https://www.facebook. com/groups/504655969882804/>, dostęp: 23.01.2021. [4] <https://www.facebook.com/astrologowiezheroesow/>, dostęp: 23.01.2021.
[5] <https://www.facebook.com/TazarToDuren/>, dostęp: 23.01.2021.

[6] <http://heroes.net.pl/>, dostęp:23.01.2021.

[7] <https://www.acidcave.net/>, dostęp: 23.01.2021.

[8] <https://www.facebook.com/heroesorchestra/>, dostęp: 23.01.2021.

[9] <https://mistrzostwa.heroes.net.pl/home>, dostęp: 23.01.2021. 
grywających role dowódców. Nie będzie nadużyciem stwierdzenie, że gry z tej serii zawdzięczają popularność atrakcyjnemu, czytelnemu systemowi reguł i rozgrywce wieloosobowej, która może odbyć się na jednym[10] bądź na wielu komputerach (za pośrednictwem Internetu). Szczegóły świata przedstawionego czy historii - choć są rozwijane w każdej odsłonie, w ramach trybu kampanii, zbioru etapów, powiązanych ze sobą spójnym wątkiem fabularnym lub tematycznym - stanowią raczej suplement do całości. W typowej rozgrywce to wyzwania[11] wychodzą na pierwszy plan. Wraz z kolejnymi tytułami wzrastała liczba immersyjnych [12] i światotwórczych zabiegów, ale główne mechaniki zostały zachowane w podobnej formie. Można wyróżnić dwa okresy rozwoju serii - najpierw powstały cztery części osadzone w fikcyjnych światach Enroth i Axeoth, za które odpowiedzialne było studio New World Computing, w 1996 roku wykupione przez The 3DO Company (Heroes of Might and Magic I: A Strategic Quest, Heroes of Might and Magic II: The Succession Wars, Heroes of Might and Magic III: Restoration of Erathia, Heroes of Might and Magic IV). Realizacje kolejnych trzech odsłon zlecił Ubisoft (Heroes of Might and Magic V, Might and Magic: Heroes VI, Might and Magic: Heroes VII). W przeciwieństwie do pierwszych gier nowsze tytuły wykorzystują trójwymiarową grafikę i opowiadają o wydarzeniach rozgrywających się w nowym uniwersum: Ashanie. W ramach tekstu chciałbym zarysować kluczowe wątki związane gatunkami i narracjami, na których opiera się seria.

\section{Oflagowanie laboratoriów alchemika, czyli kolonializm w szatach fantasy}

[10] Dzięki trybowi Hot Seat (pol. Gorące krzesła) osoby biorące udział w rozgrywce na jednym komputerze siadają przy maszynie na zmianę, zgodnie z kolejnością tur.

[11] Laura Ermi i Frans Mäyrä piszą o wyzwaniach jako o centralnych dla gier czynnikach wywołujących zjawisko immersji (zmysłowe zanurzenie poprzez kontakt z jego warstwą estetyczną może także mieć miejsce na przykład w kinie, zaś immersja związana $\mathrm{z}$ doświadczaniem fabuły występuje choćby podczas czytania powieści). L. Ermi, F. Mäyrä, Fundamental components of the gameplay experience: Analysing immersion, [w:] DIGAREC Keynote-Lectures 2009/10, eds. S. Günzel, M. Liebe, D. Mersch, Potsdam 2011, s. 101.

[12] Według Piotra Kubińskiego „Immersja to wrażenie niezmediatyzowanego uczestnictwa, bezpośredniej obecności w cyfrowej przestrzeni generowanej komputerowo, wynikające m.in. z zaangażowania wywoływanego przez różne czynniki. Użytkownika absorbuje nie tylko akcja przedstawiana na ekranie
[...], lecz także podejmowane przez niego czynności i partycypacja w świecie gry. Decydująca jest tutaj aktywność gracza - nie tylko intelektualna (na poziomie interpretacji), lecz także jak najbardziej fizyczna, związana z rzeczywistym oddziaływaniem na świat cyfrowy i faktycznym wpływaniem na bieg wydarzeń". P. Kubiński, Gry wideo. Zarys poetyki, Kraków 2016, S. 51.

[13] Dla ułatwienia będę w tekście korzystać z tego powszechnie używanego akronimu.

[14] „Strategie turowe [...] opierają się na pomyśle walki na zmianę - gracz wykonuje ruch postacią lub oddziałem po to, by następnie zrobił to komputer. W tym gatunku istotną rolę odgrywa dokładne opracowanie taktyki, bohaterom lub armiom jest bowiem przypisana ograniczona liczba punktów ruchu, strzałów, czynności." Za: J. Stasieńko, Alien vs. predator?: gry komputerowe a badania literackie, Wrocław 2005, s. 69.

[15] cRPG to gatunek ludyczny, „powiązany z różnymi efektami gatunkowymi, takimi jak rozwój postaci 
podzielony na frakcje odnoszące się do schematów gatunku: niemal zawsze pojawiają się stronnictwo elfów, ludzi, orków, nieumarłych etc.). Wszystkie odsłony wykorzystują interfejs[16] point'n'click („wskaż i kliknij"[17]) wraz z interfejsami nakładkowymi[18] o rozbudowanym aspekcie narzędziowym - tak jak w większości gier strategicznych obok reprezentacji cyfrowej rzeczywistości mamy do dyspozycji szereg niediegetycznych „belek”, za pośrednictwem których można odczytać informacje na temat „stanu królestwa” (jedna z nich informuje zazwyczaj, ile surowców gracz ma do dyspozycji, inna zaś pokazuje datę według czasu świata przedstawionego itp.), a także można wybrać na przykład konkretną postać z dostępnej puli.

Działania, jakie możemy podjąć w obrębie świata diegetycznego, rozgrywają się przede wszystkim na trzech płaszczyznach. Pierwszą z nich jest umowna, najbardziej ogólna przestrzeń, reprezentująca całą dostępną w ramach danego etapu cyfrową rzeczywistość - w obrębie serii zwyczajowo nazywana „mapą przygody”. Mimo że nie jest to profesjonalne sformułowanie, chciałbym pozostać przy nim w dalszych partiach tekstu, jako że za jego pośrednictwem można uchwycić dwoisty charakter konwencji HoMM - z jednej strony kluczowym wymiarem rozgrywki jest dosłowne przejmowanie kontroli nad mapą (warstwa strategiczna), z drugiej zaś istotną rolę odgrywa eksploracja grajobrazu przez tytułowych herosów oraz powiązany z nią rozwój (przygoda, warstwa role play). Mapa przygody wypełniona została przeróżnymi stałymi obiektami (lokacjami, które nasze awatary mogą odwiedzić oraz fragmentami terenu - na przykład drzewami - stanowiącymi przeszkodę i pełniącymi funkcję estetyczną), surowcami i artefaktami (które można zebrać), oddziałami przeciwników (broniących przejść oraz lokacji - interakcja z nimi najczęściej kończy się przejściem do areny[19], na której toczy się bitwa) i tytułowymi bohaterami, grywalnymi postaciami i jedynymi „elementami” mogącymi poruszać się po

przez zdobywanie poziomów doświadczenia lub walka oparta o system statystyczny" (za M.B. Garda, Interaktywne Fantasy. Gatunek w grach cyfrowych, Łódź 2016 [wersja MOBI]), wywodzący się z systemów RPG, stanowiących podstawę narracyjnych gier fabularnych (np. Dungeons and Dragons).

[16] Jak ujmuje to Piotr Kubiński: „Interfejsy użytkownika [...] po pierwsze tłumaczą cyfrowe dane na język zrozumiały dla niewyspecjalizowanego użytkownika i - po drugie - umożliwiają mu interakcję. [...] interfejs zakłada zwrotną relację pomiędzy użytkownikiem a urządzeniem - człowiek wydaje sprzętowi (zwykle jest to komputer) polecenia, ale jednocześnie odbiera od niego sygnały (które również mogą mieć formę polecenia albo po prostu komunikatu)”. Za: P. Kubiński, op.cit., s. 157-158.

[17] „zgodnie z nazwą wymaga on zaznaczenia kursorem odpowiedniego fragmentu oprawy gra- ficznej i potwierdzenia komendy poprzez wciśnięcie właściwego klawisza." Za: M.M. Chojnacki, Interfejs [w:] Wprowadzenie do groznawstwa, red. K. Prajzner, Łódź 2019, s. 108.

[18] P. Kubiński, op.cit., s. 187-19o.

[19] Posługuję się tutaj definicją Michaela Nitschego, według której „arena” to wydzielona przestrzeń w grze cyfrowej, która służy za „płótno” dla konkretnego działania - na przykład walki (Arenas are mostly open structures with one dominating demarcation line: the surrounding enclosement, which is essentially a datum in Ching's definition. In contrast to the labyrinth, they feature few visual clues that draw attention to the place as such. Instead, they provide the provide the canvas for a performance. Whether it is a football pitch, a boxing ring, or the coliseum, arenas provide relatively free movement in a contained space with high visibility, while labyrinths 
mapie przygody i wchodzić w interakcje ze wspomnianymi obiektami i przeciwnikami[20] - to swego rodzaju pionki, którymi sterujemy my oraz sztuczna inteligencja. Cała rozgrywka podzielona została na rundy oraz tury. Domyślnie nie ma żadnego zegara odmierzającego czas na wykonanie ruchu - gra nagradza nas za dobrze przemyślaną decyzję, a nie za refleks. Warto też wspomnieć, że twórcy urealniają tę mechanikę konwencją kalendarza[21] - jedna runda staje się odpowiednikiem dnia w świecie przedstawionym. Wraz z nastaniem kolejnej „doby” kopalnie i miasta należące do królestwa przynoszą nowe zasoby, a jednocześnie każdy awatar (oraz herosi sterowani przez komputer) może poruszać się określoną liczbę pól[22] na turę. Mimo zabiegów osadzających mechaniki w konkretnych kontekstach strefa ta stanowi prawdopodobnie najbardziej umowną przestrzeń diegetyczną gry - oddziały przeciwników zostają przedstawione za pomocą reprezentacji ich pojedynczego egzemplarza (na przykład pod wizerunkiem smoka na mapie przygody może się kryć cały oddział smoków, z którym przyjdzie nam stoczyć bitwę), zaś sami bohaterowie również stanowią w istocie symboliczne przedstawienie całej armii, złożonej z wielu różnych typów wojowników i fantastycznych potworów. Obserwujemy mapę z perspektywy izometrycznej lub z lotu ptaka - tak jak w większości gier strategicznych mamy do czynienia $z$ narracją auktorialną, nie ogranicza nas pole widzenia jednego herosa, ale możemy wydawać komendy przemieszczenia się po kolei każdej dostępnej nam postaci i widzimy cały teren, który one przemierzyły (na początku przestrzeń mapy przygody jest zasłonięta tak zwaną „mgłą wojny” - i musi zostać odsłonięta poprzez eksplorację).

Drugą płaszczyzną, na której możemy podejmować działania, są wspomniane już areny - umowne pola bitew. Po wejściu w interakcje z przeciwnikami znajdującymi się na mapie przygody lub herosami sterowanymi przez przeciwną frakcję (człowieka lub komputer - te podmioty same mogą wejść w interakcję z nami, jeśli akurat wykonują ruch), zostajemy przeniesieni do kolejnej przestrzeni (mającej reprezentować niewielki wycinek mapy przygody), na której dwie armie stoją naprzeciwko siebie. Na arenie (składającej się z pól - w większości

restrain movement to a complex space that complicates comprehension. As a result, the arena's spatial arrangement often supports events such as battles, dances, or speeches that demand skillful operation of the avatar, often in collaboration or competition with others. M. Nitsche, Video Game Spaces. Image, play, and structure in 3 d game worlds, Cambridge, MA, London 2008, s. 192).

[20] Wyjątek stanowi tu część czwarta, w której armie mogą przemieszczać się po mapie przygody bez dowódcy.

[21] Jak piszą José P. Zagal i Michael Mateas, określenie rund konkretnymi etykietkami (dni lub lat) ewo- kuje odpowiednie skojarzenia w umyśle użytkownika i wpływa na jego oczekiwania oraz percepcję czasu wewnątrz świata gry. („Labeling the rounds in a game as "days" or "years" changes a player's expectations of the granularity of action that can be accomplished in a round. Such expectations are established by activating temporal schemata in a player's mind, that is, cognitive scripts detailing default event sequences and relative durations." Za: J.P. Zagal, M. Mateas, Time in video games: A survey and analysis, „Simulation \& Gaming" 2010, XX(X), s. 7).

[22] Siatka pól jest przed nami ukryta, ale jak najbardziej organizuje ona przestrzeń „mapy przygody”. 
odsłon heksagonalnych lub kwadratowych) zgodnie z kolejnością tur poruszają się wojska (poszczególne oddziały reprezentowane są znów przez pojedynczy egzemplarz - tym razem z liczbą informującą, ile „okazów” ukrywa się pod daną reprezentacją). Osoba grająca może wykonywać ruchy dostępnymi jednostkami oraz rzucać zaklęcia bohaterem, który w większości części stoi poza polem bitwy.

Trzecia przestrzeń diegetyczna, w ramach której możemy podjąć działania, to miasta -najważniejsze obiekty w grze. Po kliknięciu na podobiznę należącej do nas metropolii przechodzimy do ekranu przedstawiającego jej panoramę. Wewnątrz tej strefy możemy wznosić użyteczne (dla gospodarki lub armii naszego królestwa) budynki za surowce zebrane na mapie przygody, prowadzić wymianę handlową, a także rekrutować nowe oddziały do armii. To jedyna płaszczyzna, która nie opiera się w tak wielkim stopniu na umowności, lecz przedstawia pozornie realistyczny obraz miasta, z głębią przestrzeni[23].

Na przykładzie omówionych przestrzeni oraz mechanik widać, że seria HoMM, tak jak wiele innych gier strategicznych, przenosi na cyfrową rzeczywistość schematy ideologii imperialnej[24], jako że wyzwania opierają się na nieustannej ekspansji i wchłanianiu innych królestw. Choć prawie wszystkie budynki i miasta są strzeżone, nie dostajemy informacji na temat tego, kto je zbudował i do kogo należą w ramach świata przedstawionego - czekają tylko na to, by po nie sięgnąć[25]. Poszerzanie imperium odbywa się poprzez eksplorację mapy przygody (cytując fragment publikacji Tomasza Z. Majkowskiego „już sam fakt umieszczania na mapie białych plam - obszarów nieodkrytych i domagających się interwencji badawczej - wiąże się z rozumowaniem w kategoriach imperialnych"[26]) i podbijania kolejnych kopalni, budynków umożliwiających pobór armii oraz obcych miast (to właśnie te obiekty są z reguły wyróżnione na minimapie, co wpisuje się w typową dla gier konwencję „oznaczenia tych elementów, które mogą się graczowi przysłużyć” [27]). Souvik Mukherjee, badacz gier strategicznych, wskazuje ponadto, że kolonializm opiera się między innymi na przekształcaniu przestrzeni na przykład poprzez wprowadzenie rodzimej flagi[28]. To schemat typowy także dla serii HoMM - gdy

[23] Musimy jedynie przymknąć oko na fakt, że każda metropolia danej frakcji wygląda tak samo, a na ulicach, poza częścią pierwszą, nie widzimy mieszkańców.

[24] Tak jak Tomasz Z. Majkowski, traktuję tu imperializm „jako zespół wyobrażeń, którego celem jest uzasadnienie politycznej, gospodarczej i kulturowej dominacji państwa silniejszego nad słabszym", T.Z. Majkowski, Języki gropowieści. Studia o różnojęzyczności gier cyfrowych, Kraków 2019, s. 238.

[25] Sybille Lames, badaczka gier strategicznych, w swoim tekście na temat Civilization III zwraca uwagę na to, że na mapie gry obecne są wioski czy barbarzyńcy - elementy kultury - które jednak potraktowane zostały jako pewne tło oraz naturalny element przestrzeni. Możemy zauważyć, że podobnie jest $\mathrm{z}$ wszelkimi kopalniami i innymi obiektami w serii HoMM - nie mają one tożsamości. vide: S. Lammes, On the border: pleasure of exploration and colonial mastery in Civilization III play the world, „DiGRA” 2003, vol. 2, s. 120-129.

[26] T.Z. Majkowski, op.cit., s. 241.

[27] Ibidem, s. 245.

[28] S. Mukherjee, Videogames and Postcolonialism: Empire plays back, Cham 2017, s. 34. 
dana konstrukcja zostaje włączona do naszego imperium, zawisają na niej flagi lub sztandary z naszymi barwami - symbolicznie podkreślając przynależność obiektu do naszego imperium.

Inne tropy charakterystyczne dla zagadnienia imperializmu, także te ekonomiczne, również zostają w dość nieoczekiwanej formie włączone w mechaniki omawianej serii. Rozwój naszego imperium zależy od rosnącego dopływu surowców, co skutkuje „binarnym podziałem między centrum a peryferiami” [29] - w ramach rozgrywki eksploatujemy kolejne tereny (poprzez zdobywanie obiektów, pokonywanie przeciwników, ale także zbieranie surowców leżących na mapie), by rozwinąć centrum naszego dominium, reprezentowane przez miasto. Nasze armie dokonują spustoszenia w cyfrowej rzeczywistości, co więcej, w Heroes of Might and Magic nie ma możliwości ucieczki przed imperialnym ekspansjonizmem - brak tu innej opcji zwycięstwa niż nieustanna, agresywna eksploracja, bo i tak każdy etap wymaga takiej strategii działania, niezależnie od wyznaczonych przez scenarzystów celów. W większości przypadków musimy pokonać przeciwników (poprzez zajęcie ich wszystkich miast), ale czasem należy też zdobyć konkretną metropolię, innym razem trzeba „oflagować” wszystkie kopalnie/siedliska danego typu stworzeń (na przykład wszystkie stawy hydr), w jeszcze innych trzeba znaleźć potężny artefakt (na mapach przygody umieszczone zostały obeliski zawierające elementy mapy ukazującej lokalizację skarbu), a w nielicznych przypadkach musimy zgładzić wrogiego herosa lub konkretne stworzenia znajdujące się na mapie przygody - nie da się tego dokonać bez eksploracji i ekspansji.

Jednocześnie należy zauważyć, że w przeciwieństwie do niektórych tytułów ta kolonizacja i agresywna ekspansja odbywa się w sztucznej rzeczywistości (nie odgrywamy ani nie przetwarzamy historii naszego świata), ale także pomija zupełnie zagadnienia społeczne. Gry z serii HoMM nie skupiają się w żadnym stopniu na ludności cywilnejmieszkańcy są niewidoczni, choć łatwo możemy dostrzec budynki mieszkalne, a ktoś musi też wydobywać surowce. W ramach świata przedstawionego liczą się wyłącznie wojska i ich dowódcy-herosi - co wzmacnia umowność rozgrywki.

Miecz i magia konwencja heroic fantasy i gatunek cRPG w HoMM
Nie można pominąć faktu, że obok budowania królestwa i ekspansji wyzwaniem jest także rozwijanie postaci. Podtytuł pierwszej gry - A Strategic Quest - w wyrazisty sposób streszcza charakter serii, opartej na połączeniu wątku militarnego - strategicznego rozwijania imperium - z charakterystycznym motywem questu, czyli „misji, wędrówki, poszukiwań” (jednego z podstawowych elementów porządkujących strukturę gatunku fantasy[30]).

Nie mamy do dyspozycji jedynie armii - sterujemy przede wszystkim herosami, którzy mają imiona, podobizny, specjalizacje,
[29] Ibidem, s. 35 .
[30] G. Trębicki, Fantasy. Ewolucja gatunku, Kraków 2009, s. 32. 
krótkie biogramy, miejsce na artefakty (stanowiące ekwiwalent oręża i zbroi z gier fabularnych), a od ich atrybutów i umiejętności zależy tak naprawdę skuteczność wojska - wszystkie te elementy związane są z gatunkiem cRPG[31]. Za jego fundamentalne cechy Maria B. Garda uznaje: 1) postęp gry napędzany przez opowiadanie historii (story driven), 2) wybory, które przynoszą konsekwencje dla dalszej rozgrywki, 3) wybór klas postaci, 4) zdobywanie poziomów doświadczenia, 5) łup zdobywany na wrogach, 6) wytwarzanie nowych przedmiotów (crafting), 7) dostosowywane przez użytkownika wyposażenie postaci (customization)[32]. Pierwsze trzy wartości związane są z „wchodzeniem $\mathrm{w}$ rolę”, kolejne cztery - $\mathrm{z}$ „rozwijaniem postaci”. Punkty te występują w poszczególnych częściach serii z różną intensywnością, ale wraz z jej rozwojem możliwości kształtowania herosów ulegały rozwinięciu.

W pierwszej części HoMM z gatunku cRPG zaczerpnięto klasy postaci (rycerza, czarodziejkę, barbarzyńcę i czarnoksiężnika), obecność podstawowych statystyk (w tym przypadku są to: atak, obrona, moc oraz wiedza) i możliwość przydzielania bohaterowi artefaktów zwiększających owe statystyki (artefakty te znajdujemy na mapie przygody). Koncepcja ta była rozwijana w kolejnych odsłonach - w drugiej części wprowadzono umiejętności, które postacie zdobywają po awansie na kolejny poziom doświadczenia. W kolejnej postacie zaczynały grę z własną, niekiedy oryginalną dla siebie specjalnością (dodatkową umiejętnością). Pojawiły się także krótkie biogramy pogłębiające immersję - dzięki nim herosi zostali zakotwiczeni w świecie przedstawionym. Odsłony rozgrywające się w Ashanie dodały jeszcze jeden ważny element - każda frakcja otrzymała specyficzną dla siebie umiejętność frakcyjną (na przykład czarodzieje potrafią sami konstruować artefakty - pojawia się więc nawet wspomniany crafting).

Ciekawe zmiany w tej sferze oferuje Heroes of Might and Magic $I V$, odsłona, w ramach której nasze oddziały mogą podróżować po mapie przygody bez herosów, zaś sami herosi stoją na polu bitwy obok szeregowych żołnierzy - stają się figurami aktywnie uczestniczącymi w walce i mogą także stanowić jedyny komponent oddziału - przez co odsłona ta umożliwia skonstruowanie drużyny rodem ze standardowego tytułu cRPG, zamiast armii - a tym samym przybliża się w stronę tego gatunku. Jeszcze inny eksperyment wprowadza Might and Magic: Heroes VI, tytuł, który daje możliwość kreowania postawy etycznej swojego bohatera - poprzez wybór pozytywnej „drogi łez” oraz negatywnej „drogi krwi”. Ścieżkę obieramy w trakcie rozgrywki, gdy bohater zdobywa

[31] Zgodnie z koncepcją zaproponowaną przez Geralda A. Voorheesa, Joshuę Calla i Katie Whitlock (Za: M.B. Garda, Gatunek, [w:] Wprowadzenie do groznawstwa..., s. 84), a rozwiniętą w publikacji Marii B. Gardy, gatunki gier można rozpatrywać w trzech ujęciach: tematycznym (związanym $\mathrm{z}$ warstwą fabularną i reprezentacyjną), ludycznym (dotyczącym mechanik i struktur) i funkcjonalnym (skupionym na celu, jakiemu ma służyć dany utwór). Następny segment tekstu skupiać się będzie na ewolucji gatunku tematycznego (szczególnie w kontekście jego literackich źródeł), natomiast teraz zamierzam poruszyć kwestię rozwoju drugiego, obok strategii, gatunku ludycznego, za: M.B. Garda, op.cit.

[32] M.B. Garda, Gatunek..., s. 84, rysunek 6. 
wystarczającą liczbę punktów łez lub krwi - te zaś otrzymuje za podjęte wybory w trakcie rutynowych dla serii HoMM interakcji na mapie przygody. Przykładowo: jeśli przeciwnicy są mniej liczni od naszego oddziału, postanawiają ratować się ucieczką. W każdej odsłonie możemy zdecydować, czy chcemy wybić uciekinierów, czy też pozwalamy im zbiec. W szóstej odsłonie za okrucieństwo wobec nich otrzymujemy „punkty krwi”, a za litość „punkty łez” - tym samym ta odsłona poddaje rewizji typowe dla tej serii motywy i nakłada jakąś formę oceny moralnej na decyzje, których ciężaru do tej pory nie odczuwaliśmy (trzeba natomiast zaznaczyć, że zdobycie odpowiedniej liczby punktów krwi nie ma negatywnych skutków - wręcz przeciwnie, pozwala rozwinąć naszą postać w tym samym stopniu co punktyłez, a i tak, niezależnie od tych współczynników, agresywna ekspansja stanowi jedyną strategię).

Jednocześnie, wziąwszy pod uwagę to skupienie na postaciach herosów i gatunku cRPG, nie można pominąć związku serii z konwencją heroic fantasy - gry HoMM łączy z nią nie tylko tytuł, typy postaci czy motyw questu, ale także i sam model rozgrywki zdaje się być pewnym jej odzwierciedleniem:

Akcja heroic fantasy toczy się w czasoprzestrzeni awanturniczej, która wedle Michaiła Bachtina jest abstrakcyjna, bowiem nie odgrywa w niej większej roli konkretyzacja geograficzna i historyczna [...]. Skoro protagonista poddany jest przygodom, to przestrzeń pozostaje dla niego raczej nieznana, a z pewnością obca i wroga. Peregrynacji bohatera nie rozdzielają opisy wędrówki lub podróży, chyba że ta jest pretekstem do zaistnienia kolejnego zagrożenia, z którym ten musi się zmierzyć[33].

Podobnie można przedstawić eksplorację mapy przygody w standardowej rozgrywce - jako podróż przez nieznany, pełen niebezpieczeństw ląd, w trakcie której herosi stawiają czoła kolejnym wyzwaniom. Można tu postawić tezę (szczególnie gdy mowa o pierwszych odsłonach, w ramach których różnice między dostępnymi frakcjami nie są tak znaczące[34]), że pozbawione tożsamości armie stanowią modyfikowalny „oręż” w rękach herosa, wykorzystywany w trakcie bitwy z monstrami. Tej konwencji rzuca wyzwanie jednak tryb kampanii, w ramach którego twórcy postanowili wprowadzić bardziej skomplikowane schematy narracyjne.

Fabularyzacja[35] mechanik serii w grach wyprodukowanych przez New World Computing

[33] T. Smejlis, Konwencja heroic fantasy w grach fabularnych, „Homo Ludens” 2011, nr 1/(3), s. 187. [34] W pierwszych częściach same gry dostarczają nam mniej informacji na temat istot, które możemy wcielić do swojej armii - a same istoty nie mają tylu wyjątkowych zdolności i nie są tak silnie związane ze swoimi macierzystymi frakcjami.

[35] W następnych akapitach skupię się na zagadnieniu fabuły w kontekście kampanii do gier z serii HoMM - nie oznacza to jednak, że standardowe eta- 
pochodzących z mitologii, religii oraz dzieł literackich, a zostały one powiązane ze sobą w taki sposób, by stanowiły czytelne zbiory, łączące się z konkretnymi schematami. Na tym poziomie interakcji z grą mogą zatrzymać się zarówno gracze casualowi, niezaangażowani (poszukujący niezobowiązującej rozrywki), jak i hardcore’owi, zaangażowani (dążący do wnikliwego zgłębienia reguł oraz statystyk poszczególnych istot, w celu opracowania odpowiednich strategii gry)[36].

Mimo to w ramach kampanii[37] twórcy usiłują opatrzyć nowymi kontekstami frakcje dostępne do wyboru w standardowym trybie gry. Nie widać tego jeszcze w Heroes of Might and Magic: A Strategic Quest (1995). Koncepcja kampanii opiera się na starciu czterech władców - Rycerza, Czarodziejki, Barbarzyńcy i Czarnoksiężnika. Każda z postaci walczy o władzę w niedookreślonej krainie, a choć możemy wybrać, po której stronie się opowiemy, decyzja ta stanowi tak naprawdę tylko wybór strategii gry (głównie: istot, jakie będziemy mieli do wyboru). Być może w tym przypadku słowo „fabuła” byłoby nieodpowiednim określeniem - w kampanii pierwszej odsłony serii brakuje wyraźnego aktanta, „postaci uczestniczącej w fabule, która jest gwarancją identyfikacji zdarzeń" [38]. Dominującym sposobem prezentacji informacji fabularnych są obecne przed każdym etapem, paratekstowe, krótkie opisy i tytuły, wprowadzające nas w zadania danego scenariusza, ale nie mówią one nic o postaci, w imię której (według założeń kampanii) walczymy.

Druga odsłona - Heroes of Might and Magic II: The Succession Wars (1996) - oferuje bardziej złożoną koncepcję kampanii i ukazuje zdarzenia za pomocą różnorodnych środków. Novum stanowi rozpoczynające ją intro (krótki, animowany filmik wprowadzający), w ramach którego lektor zapoznaje nas ze szczegółami konfliktu między dwoma braćmi - dobrym Rolandem i złym Archibaldem[39]. Przed rozpoczęciem kampanii można wybrać stronę jednego $\mathrm{z}$ nich - nie są stricte protagonistami, bo wydają nam rozkazy przed każdą kolejną misją, ale najbliżej im do realnych postaci w tej odsłonie. W przeciwieństwie do pierwszej części widzimy sedno konfliktu - walczymy o ratunek dla

py gry jednoosobowej lub wieloosobowej z zasady są jej pozbawione. W niektórych przypadkach scenariusze przypominają swoją złożonością etapy kampanii.

[36] Korzystam tutaj zarówno z opozycji hardcore/casual, jak i propozycji jej doprecyzowania, wysuniętej przez Pawła Grabarczyka, który proponuje określenia „angażująca” i „nieangażująca”. P. Grabarczyk, Opozycja hardcore/casual, [w:] Wprowadzenie do groznawstwa..., s. 127-148.

[37] Oczywiście większość gier strategicznych oferuje warstwę fabularną w postaci kampanii, niezależnie od tego, czy mowa o tytułach osadzonych w historycznej scenerii - Twierdza (2001, Firefly Studios), Age of Empires (1997, Ensemble Studios), Empire Earth (2001, Stainless Steel Studios) - czy o grach, które również rozgrywają się w realiach fantasy: Władca pierścieni: Bitwa o Śródziemie (2004, Electronic Arts), Warcraft 3 (2002, Blizzard Entertainment).

[38] J. Stasieńko, op.cit., s. 94.

[39] Sam ten monolog budzi skojarzenia ze stereotypowo rozumianą baśnią, ale opowieść narratora nie zgadza się z informacjami ukazanymi na oszczędnych animacjach (mowa jest na przykład o śmierci wieszczów, którzy mieli wskazać prawowitego dziedzica głos wspomina o nieszczęśliwych wypadkach, lecz scenki sugerują, że to „zły brat” Archibald w rzeczywistości ich zamordował), co od razu buduje ironiczny dystans do konfliktu - widać, że twórcy tej części przedstawiają elementy fabularne w konwencji buffo. 
królestwa albo o zapanowanie w nim zła. Poznajemy też lepiej sam świat przedstawiony - dostajemy szczątkowe informacje geopolityczne (na przykład celem jednej z misji rozgrywanych po stronie dobra jest przekonanie krasnoludów do walki za sprawę Rolanda[40] - to nieskomplikowany wątek, ale dowiadujemy się dzięki niemu, że krasnoludy stanowią w tym świecie nieco bardziej niezależną grupę kulturową, mimo że w ramach rozgrywki przynależą do jednego zbioru fantastycznych stworzeń związanymi z pozytywnie nacechowaną naturą). W dodatku po jednym z etapów można zmienić stronę konfliktu i dokończyć kampanię pod rozkazami drugiego z braci. Mamy zatem do dyspozycji więcej możliwości rozwijania opowieści i możliwość zadecydowaniu o wyniku konfliktu (co należy do tradycji gatunku cRPG).

W Heroes of Might and Magic III: Restoration of Erathia (1999), najbardziej popularnej odsłonie serii, twórcy poszli krok dalej w poszerzaniu możliwości formuły i rozwijaniu warstwy fabularnej. Warto zwrócić uwagę na sam monolog w filmie otwierającym grę[41]. Tym razem w rolę narratorki wciela się główna bohaterka opowieści, królowa Katarzyna Ironfist, małżonka Rolanda z poprzedniej odsłony, która wraca do swojej ojczyzny. W czołówce pojawiają się bardziej skomplikowane nazwy - „Enroth”, „Flota Regna”, „Erathia”, a później także „zamek Cloudfire" - co stanowi wyraźny sygnał, że nowa gra oferuje bardziej doprecyzowany i rozbudowany świat przedstawiony. W przeciwieństwie do uproszczonego konfliktu z Heroes of Might and Magic II mamy też do czynienia z wojną między dwoma państwami/kulturami[42]. Tej części znacznie bliżej jest do konwencji fantasy epickiej[43]. Dodatki do gry wprowadzają ponadto koncepcję protagonistów kampanii - postaci

[40] Nie łudźmy się jednak, że pojawia tu jakiś element dyplomacji - tak jak w innych etapach najlepszym sposobem na zwycięstwo jest zatknięcie flagi w każdym miejscu na mapie przygody.

[41] Rozwój technologii pozwolił na skonstruowanie pełnej, krótkiej sekwencji filmowej - tym razem zrealizowanej w poważnym kluczu. Warto wspomnieć też o tym, że w tej części animacje przed scenariuszami kampanii są mniej minimalistyczne - przedstawiają zapętlone scenki, ukazujące mieszkańców krainy lub kluczowe postaci.

[42] Sama kampania została podzielona na kilka segmentów. Gra zmusza nas do tego, byśmy poznali perspektywę każdej ze stron konfliktu, zanim przejdzie do kolejnego etapu opowieści - nie jest to ten sam poziom „kontroli” nad konfliktem, co w przypadku HoMM, ale tym razem mamy do czynienia z mniej czarno-białą opowieścią Każde stronnictwo związane jest z konkretnym królestwem/państwem z uniwersum (i od tej pory już zawsze tak będzie). Frakcje w kolejnych częściach będą miały swoje tła historyczne i władców, a ich miejsce na mapie politycznej zostanie wyjaśnione w ramach kampanii.
[43] Według Trębickiego cechy fantasy w formie epickiej „powieści-rzeki” to: „1) Przyjmowanie postaci [...] wielowątkowej [...]. 2) Nakreślenie niezwykle szerokiej panoramy określonych wydarzeń historycznych (wojny, walka polityczna, przemiany społeczne) rozgrywających się w świecie przedstawionym utworu oraz położenie nacisku na tematykę historiozoficzną. 3) Ograniczenie roli tradycyjnie rozumianego protagonisty (lub nawet jego całkowite zniknięcie $\mathrm{z}$ tekstu) przy jednoczesnym zwiększeniu się liczby opisywanych postaci; pojawienie się bohatera zbiorowego. 4) Rezygnacja z dualistycznej wizji świata przedstawionego, jak również z prezentacji walki Dobra ze Złem na skalę kosmiczną na rzecz przedstawienia skomplikowanej mozaiki różnego rodzaju sił kształtujących losy świata przedstawionego. 5) Stopniowe zanikanie elementów związanych z tradycją mitu, romansu rycerskiego i eposu bohaterskiego oraz pojawianie się elementów świadczących o pokrewieństwie ze współczesną mimetyczną powieścią historyczną i wojenną. Za: G. Trębicki, op.cit., s. 111-112. 
wiodących, które rozwijają się z kolejnymi etapami za pośrednictwem dialogów oraz opisów wewnętrznych przeżyć, pojawiających się w trakcie danego etapu w oknach tekstowych.

Ewolucję Heroes of Might and Magic IV (2002) w symboliczny sposób podsumowuje intro wprowadzające do gry, w ramach którego dowiadujemy się, że planeta Enroth (gdzie toczyła się akcja poprzednich odsłon), uległa zniszczeniu, zaś część jej mieszkańców uciekła przez portale do nowego świata: Axeoth. Gra nie ma postaci wiodącej i głównego konfliktu, jak w przypadku Wojny o sukcesję czy Odrodzenia Erathii, a każda z sześciu kampanii powiązana została $\mathrm{z}$ konkretną frakcją i protagonistą bądź protagonistką. Nie łączą się one w większą narrację, lecz ukazują kształtowanie się sił w Nowym Świecie, oferując przy tym bardziej rozbudowaną warstwę literacką - okna tekstowe zawierają więcej dialogów i monologów wewnętrznych niż poprzednia część. Heroes of Might and Magic IV prezentuje interesujące ujęcie formuły fantasy poprzez pogłębienie świata przedstawionego i ukazanie losów zróżnicowanych jednostek, próbujących poradzić sobie z życiem po kataklizmie. Ta część wieńczy jednak historię rozwoju światów Enroth i Axeoth - a także kończy erę dominacji literatury w obrębie serii.

Co ciekawe (i niezamierzone, a raczej związane z gwałtownym rozwojem samego medium), ewolucja warstwy fabularnej gier wyprodukowanych przez New World Computing Company stanowi odbicie rozwoju fantasy w literaturze - od baśni rozgrywającej się w niesprecyzowanym „nigdzie”, poprzez coraz bardziej rozbudowane struktury światoopowieściowe (koncepcje dopracowanych, w pełni fikcyjnych uniwersów, rozwinięte przez „ojców” całego gatunku, Roberta E. Howarda i J.R.R. Tolkiena), po formy hybrydowe (w gruncie rzeczy można uznać Heroes of Might and Magic IV za specyficzny przykład fantastyki postapokaliptycznej) [44]. To jednak nie jedyny wpływ literatury na serię - szczególnie w części czwartej konwencje powieściowe przejęły rolę w budowaniu dramaturgii, gdyż rozbudowane opisy przeważają nad jakimkolwiek innym środkiem wyrazu. To jednocześnie sprawia, że śledzenie losów postaci wymaga więcej uwagi i zmienia dynamikę rozgrywki (jeśli użytkownik chce w pełni uważnie śledzić fabułę, musi przerwać podboje i poświęcić kilka minut na przeczytanie kolejnych segmentów tekstu). Gracz poznaje poprzez te formy literackie bohaterów i wątki (na przykład konflikty wewnętrzne protagonistów), przy konstruowaniu których pozostałe elementy języka gry nie biorą udziału. Dziś ten sposób prezentowania fabuły może mieć efekt emersyjny (wymusza on przerwanie rozgrywki).

Gry wyprodukowane przez Ubisoft zostały zrealizowane w pełnym trójwymiarze, co ma konsekwencje także w kontekście konstruowania opowieści. Wprowadzone do gry 3D ma w zamierzeniu uczynić

Światoopowieść w grach wyprodukowanych przez Ubisoft
[44] Wciąż jednak motywem przewodnim jest howardiańska fantasy heroiczna - na co wskazuje przede wszystkim obecność tytułowych herosów miecza i magii, przemierzających krainy w poszukiwaniu wyzwań. 
świat przedstawiony mniej umownym. Jednym z nowych sposobów opowiadania są scenki filmowe pojawiające się nie tylko jako intro przed kolejnymi etapami, ale także w trakcie gry - choć bohaterowie mają dość ograniczone animacje, to po raz pierwszy możemy zobaczyć bezpośrednie interakcje między nimi. Co ważne - postacie od tej chwili mają głos, który możemy usłyszeć we wspomnianych przerywnikach i na samej mapie przygody. Tym razem to środki filmowe staną się najważniejszym środkiem wprowadzania informacji fabularnych i rozwijania relacji między postaciami (przynajmniej w części piątej i szóstej w najnowszej odsłonie zrezygnowano $\mathrm{z}$ animowanych przerywników).

Fabuła piątej części stanowi zbiór motywów znanych z poprzednich odsłon, warto więc skupić się na jej sequelach. W każdej z kampanii Might and Magic: Heroes VI (2011) wcielamy się w jedno z dzieci Sławoja Gryfa, a ich losy splecione zostają z poszczególnymi frakcjami z gry (przykładowo - jeden z synów trafia do piekła i staje na czele napotkanych demonów, zaś najmłodsza z córek zostaje zabita i wskrzeszona jako nieumarła, dlatego też dołącza do frakcji nieumarłych). Poszczególne etapy tworzą spójną układankę - opowieść o konflikcie rozdzierającym świat przedstawiony- ukazaną z różnych perspektyw[45]. W kampanii rolę grają również wspomniane wcześniej punkty łez i krwi - niektóre dodatkowe zadania dedykowane są graczowi, który wybrał jedną z tych dróg, a ukończenie linii fabularnych po stronie łez lub krwi odblokowuje też odpowiednio pozytywne bądź negatywne zakończenie (w pierwszym musimy pokonać głównego antagonistę, a w drugim stajemy po jego stronie). Mamy zatem jeszcze większy wpływ na rozwój naszego bohatera oraz wynik konfliktu, więc szósta odsłona znów zaczerpnęła więcej elementów z gatunku cRPG[46].

Might and Magic: Heroes VII (2015) w warstwie fabularnej oferuje mniej skomplikowaną strukturę. Imperium znane z części VI upadło, a książę Iwan Gryf, potomek Sławoja, zastanawia się, co uczynić w związku z wojną domową toczoną między pomniejszymi, ludzkimi władcami. W tym celu zwołuje radę złożoną z przedstawicieli różnych ras, którzy raczą młodego władcę opowieściami o wybitnych czynach ich przodków lub pobratymców. Historie mają dla niego stanowić lekcję (na przykład ork opowiada o wyzwoleniu swoich przodków spod jarzma magów, elf o wyprawie żeglarzy ze swojego ludu itp.) i pomóc podjąć decyzję. W ramach każdej z indywidualnych kampanii wcielamy się w postacie, o których opowiadają członkowie i członkinie rady Iwana Gryfa, a po zakończeniu wszystkich wątków otwiera się przed

[45] Mimo że te kampanie w zamyśle stanowić mają spójny organizm, gracz ma do wyboru, którą z nich chce najpierw rozegrać, i nie dostaje wskazówek na temat chronologii fabularnej - tych informacji twórcy nie podają w obrębie gry (można jednak znaleźć próby zrekonstruowania chronologicznej struktury na fanowskich forach internetowych).
[46] Co ważne, w panelu wyboru kampanii widnieje mapa topograficzna ukazująca najważniejszy (dla fabuły gry) fragment Ashanu, zaś na niej zaznaczono lokacje, w których rozgrywają się poszczególne etapy. Dzięki temu możemy zorientować się w przestrzeni świata przedstawionego (wiemy, gdzie znajdują się poszczególne postacie) i lepiej poznać wykreowaną przez twórców rzeczywistość. 
nami epilog, w którym wcielamy się w samego Iwana. Taka szkatułkowa struktura kampanii pozwala przyjrzeć się bliżej procesom i momentom z historii świata przedstawionego (podkreślając tym samym wyjątkowy charakter poszczególnych kultur i istotnych dla nich wydarzeń).

W kontekście owego zwrotu, w ramach którego późniejsze odsłony zaczęły skupiać się na konstruowaniu światoopowieści, warto wspomnieć, że zmienił się sposób kodowania poszczególnych frakcji. Z czasem „złe stronnictwa” wyrosły na siły pozytywne, a te „szlachetne” przejęły role antagonistów. Widać to doskonale na przykładzie frakcji ludzi, którzy coraz częściej związani byli z zagadnieniem religijnego fanatyzmu lub kolonializmu, a jednocześnie należy podkreślić, że gracz zawsze ma możliwość kontroli nad ludzkim protagonistą, który wyróżnia się na tle panującej w jego frakcji władzy lub innych, zepsutych przedstawicieli swojego gatunku. Miejsce człowieka w standardowym fantasy znajduje się w centrum i seria nie przełamuje tej zasady. Twórcy gry zapewne wychodzą z założenia, że to z człowiekiem gracze będą się w pierwszej kolejności utożsamiać i nieco „faworyzują” go na tle innych ras czy stronnictw[47]. Człowiek jest też najczęściej umieszczany na okładce, choć zapewne w głowach graczy to nie on stanowi pierwszą „postać”, z którą kojarzą serię. Ten antropocentryzm - w ramach którego to do ludzi należy najważniejsza historia i perspektywa - jest jednak typowy dla całego gatunku.

Jednocześnie, w kontekście wcześniejszych wątków kolonialnych, należy zaznaczyć, że niektóre elementy świata przedstawionego - szczególnie w obrębie gier wyprodukowanych przez Ubisoft - uwikłane są w specyficzną formę orientalizmu. Część frakcji powiązano z stereotypami na temat konkretnej kultury. Stronnictwo ludzi pozostaje konstruowane na podstawie jednego klucza: zachodnioeuropejskiego, quasi-średniowiecza, zaś nieludzie wiązani są ze stereotypami na temat kultur spoza europejskiego kręgu[48]. Najbardziej wyrazisty i specyficzny przykład tego podejścia stanowi Sanktuarium - stronnictwo wprowadzone w części szóstej, wzorowane na feudalnej Japonii. Pod względem ubioru, oręża, tradycji (mamy, rzecz jasna, do czynienia $z$ honorowymi samurajami), języka (postacie pochodzące z tego stronnictwa wplatają w swoje wypowiedzi japońskie słowa), architektury, organizacji społecznej (nad poszczególnymi armiami panują daimyō) Sanktuarium stanowi fikcyjny, fantastyczny, skonstruowany na bazie stereotypów odpowiednik Japonii, tyle że zamieszkiwany nie przez ludzi, lecz przez nagów, istoty o ciałach półczłowieka-półwęża. To wyjątkowo niefortunny koncept - a dodatkowy problem wprowadza fakt, że w ramach kampanii poświęconej Sanktuarium ludzka protagonistka wykorzystuje instrumentalnie siły nagów, by zemścić się na tyranie sie-

[47] Ma to jednak praktyczne zastosowanie, bo najłatwiej jest przedstawić odbiorcy świat za pośrednictwem perspektywy i motywów, które zna najlepiej dlatego kampanie frakcji ludzi często stanowią także wprowadzenie do gry.
[48] Przykładowo: we frakcji magów, inspirowanej indyjskimi i bliskowschodnimi cywilizacjami, czarodzieje noszą turbany, jeżdżą na słoniach i żyją w biało-złotych pałacach zbudowanych na piasku. 


\section{Granice konwencji}

jącym zamęt w jej ojczyźnie. Mimo że mamy do czynienia z fikcyjnym uniwersum, kolonialne narracje wkradają się do niego także ze strony światotwórczej i fabularnej.

W świecie Ashan pojawiały się historie o potencjale dekolonizacyjnym - stojące w opozycji do narracji imperialistycznych, na przykład $\mathrm{w}$ ramach kampanii części siódmej przedstawiających wyzwolenie orków spod jarzma ludzi i czarodziejów. Jak jednak widać na przykładzie analizy gier strategicznych autorstwa Mukherjeego [49], w tym gatunku dekolonizacja dokonuje się również poprzez metody kolonialne/imperialistyczne - agresywną ekspansję i zagarnianie przestrzeni. Nawet jeśli protagonista wyzwala swój lud, jego droga - w ramach mechanik proponowanych przez grę - będzie się opierała dokładnie na tym samym schemacie, co droga kolonizatora. Gra niejako wymaga od nas, byśmy zaczynali ją od eksploracji i ekspansji.

Hybrydyczny charakter serii sprawia, że pozwala ona opowiadać narracje zarówno na temat losów fantastycznych królestw oraz kultur, jak i jednostek - obok potencjału znajdują się jednak pułapki i ograniczenia. Jako że historie w kampanii stają się jeszcze bardziej osobiste, warstwa strategiczna może pozostać po prostu pewną ramą dla opowieści o jednostce, ale najpewniej będzie to opowieść, gdzie postacią wiodącą będzie dowódca lub monarchini - nie mamy dostępu do szczegółów dotyczących choćby codzienności ludności cywilnej z Erathii czy Ashanu i istotne wymiary świata przedstawionego zostają zawsze w ukryciu. Z tego powodu też, choć w ramach każdej kolejnej kampanii, twórcy korzystali z nowych środków wyrazu i pogłębiali światy przedstawione, opowieści zawsze borykały się nie tyle z ograniczeniami technicznymi, ale i ograniczeniami gatunku oraz konwencji wykształconych w ramach serii[50].

Chojnacki M.M., Interfejs [w:] Wprowadzenie do groznawstwa, red. K. Prajzner, Łódź 2019

Ermi L., Mäyrä F., Fundamental Components of the Gameplay Experience: Analysing Immersion, [w:] DIGAREC Keynote-Lectures 2009/10, eds. S. Günzel, M. Liebe, D. Mersch, Potsdam 2011, s. 88-115

Garda M.B., Interaktywne fantasy. Gatunek w grach cyfrowych, Łódź 2016

Grabarczyk P., Opozycja hardcore/casual, [w:] Wprowadzenie do groznawstwa, red. K. Prajzner, Łódź 2019, s. 127-148

Krawczyk S., „Przed wyruszeniem w drogę należy zebrać drużynę”. Dlaczego gry komputerowe z przełomu wieków wplynęły na tożsamość polskich graczy?, „Homo Ludens" 2015, nr 2 (8), s. 63-79

[49] Autor opisuje przede wszystkim przypadek innej turowej strategii - Empire: Total War (2009). S. Mukherjee, op. cit., s. 44 .

[50] W ramach konwencji, na których opiera się seria HoMM, nie da się realizować np. założenia gropowieści - typu gry, który (według propozycji Tomasza Z. Majkowskiego), miałby umieścić bohatera $\mathrm{w}$ „świecie o pretensjach do ujęcia totalnego i pozwolić mu na ten świat oddziaływać”. T.Z. Majkowski, op.cit., s. 38 . 
Kubiński P., Gry wideo. Zarys poetyki, Kraków 2016

Lammes S., On the border: pleasure of exploration and colonial mastery in Civilization III play the world, "DiGRA" 2003, vol. 2, s. 120-129

Majkowski T.Z., Języki gropowieści. Studia o różnojęzyczności gier cyfrowych, Kraków 2019

Mukherjee S., Videogames and Postcolonialism: Empire plays back, Cham 2017

Nitsche M., Video Game Spaces. Image, play, and structure in $3 d$ game worlds, Cambridge, MA, - London 2008

Prajzner K. (red.), Wprowadzenie do groznawstwa, Łódź 2019

Smejlis T., Konwencja heroic fantasy $w$ grach fabularnych, „Homo Ludens” 2011, nr 1/(3), s. 182-197

Stasieńko J., Alien vs. predator?: gry komputerowe a badania literackie, Wrocław 2005

Trębicki G., Fantasy. Ewolucja gatunku, Kraków 2009

Zagal J.P., Mateas M., Time in video games: A survey and analysis, „Simulation \& Gaming" 2010, XX(X), s. 1-25 